of bond-strengths, it may be expected to be of significance in other reactions.

Salts other than those of silver may be employed in the conversions; lead chloride and cadmium chloride have been used, for example, to convert hexaethylthiodisiloxane to triethylchlorosilane; but the silver salts seem to be generally satisfactory. For trimethylsilicon derivatives the series

$$
\mathrm{Me}_{3} \mathrm{SiI} \rightarrow\left(\mathrm{Me}_{3} \mathrm{Si}\right)_{2} \mathrm{~S} \rightarrow \mathrm{Me}_{3} \mathrm{SiCl} \rightarrow \mathrm{Me}_{3} \mathrm{SiNCS}
$$

has so far been confirmed, and the series given for triethylsilicon derivatives may prove to be of general applicability. The series will probably be extended to include electronegative groups other than the holides, pseudohalides and sulphide listed.

Hexaethylthiodisiloxane (b.p. 278-279\%750 mm.) and hexamethylthiodisiloxane (b.p. $162 \cdot 5^{\circ} / 735 \mathrm{~mm}$.) are the first organosilicon sulphides to be reported, and are of particular interest in view of the presentday importance of siloxanes. The weakness of the $\mathrm{Si}-\mathrm{S}$ bond relative to the $\mathrm{Si}-\mathrm{O}$ bond suggests, however, that the behaviour of thiosiloxanes will not show many analogies to that of siloxanes.

The investigation is proceeding, and a full discussion of the results will be submitted for publication elsewhere.

University College,

Leicester. Dec. 22

' Forbes and Anderson, $J$. Amer. Chem. Soc., 70, 1043, 1222 (1948). Anderson, ibid., 69, 3049 (1947); 70, 1220 (1948); 71, 1801 (1949)

${ }^{2}$ Eaborn, J. Chem. Soc., 2755 (1949).

${ }^{3}$ Pauling, "Nature of the Chemical Bond", 53 (1940).

\section{Mechanism of the Nitration of Starch}

IN studying the nitration of maize and potato starch, we observed that : $(a)$ a mixture of nitric and sulphuric acids, containing a high proportion of pseudo-nitric acid, namely, an equimolecular mixture of water, nitric and sulphuric acid', leads to the formation of nitric esters of low nitrogen content ( $7 \cdot 1$ per cent) ; (b) in the nitration of starch by means of such mixed acids containing decreasing quantities of water and increasing amounts of free sulphur trioxide, the degree of nitration of starch is controlled by the proportion of water and sulphur trioxide, respectively, in the nitrating mixture. Nitrates of starch, containing about 13 per cent of nitrogen, could be obtained easily when mixtures of pure nitric acid and oleum ${ }^{2}$ (2-3 per cent sulphur trioxide) were used. A similar observation has been reported by Fabel $^{3}$ in the case of the nitration of cellulose. Caesar et al. ${ }^{4}$ have also found that starches, cellulose and disaccharides are completely and rapidly nitrated by nitrogen pentoxide and that the nitrates thus produced have an unusually high nitrogen content (about 13.9 per cent).

These observations suggest that in the above nitration reaction it is not pseudo-nitric acid which represents the active agent ${ }^{5}$, but rather a strongly electrophilic molecular species. It is submitted that the active agent is the positive nitronium ion $\left(\mathrm{NO}_{2}{ }^{+}\right)$ recently identified as the nitrating species in the nitration of aromatic systems ${ }^{6}$ :

$$
\mathrm{HNO}_{3}+2 \mathrm{H}_{2} \mathrm{SO}_{4} \rightleftharpoons\left(\mathrm{NO}_{2}{ }^{+}\right)+\mathrm{H}_{3} \mathrm{O}^{+}+2 \mathrm{HSO}_{4}+\text {. }
$$

Conditions which favour the formation of the nitronium ion led to nitrates of high nitrogen content. One would also assume that nitrogen pentoxide reacts as nitronium ion, so that the structure of $\left(\mathrm{NO}_{2}\right)^{+}\left(\mathrm{NO}_{3}\right)^{-}$should be ascribed to its 'reactive state'?

It may be recalled that Chedin ${ }^{8}$ and Chedin and Pradier ${ }^{9}$ observed for nitrogen pentoxide a different Raman spectrum in chloroform or carbon tetra. chloride on one hand, from that in sulphuric acid or the solid state on the other. They explained the difference on the hypothesis that the group $\mathrm{NO}_{2}+$ : or a polymer of the pentoxide is present in the sulphuric acid solution.

One is tempted to suggest that the formation of the nitrates is due to an attack of the nitronium ion on a lone electron pair of the hydroxyl oxygen, followed by elimination of a proton from the intermediate product.

$$
\begin{gathered}
\mathrm{H}-\underset{\mid}{\mathrm{C}}-\ddot{\mathrm{O}}: \mathrm{H}+\mathrm{NO}_{2}^{+} \rightleftharpoons\left[\mathrm{H}-\underset{\mid \mathrm{C}-\underset{\mathrm{H}}{\ddot{\mathrm{O}}}: \mathrm{NO}_{2}}{\ddot{\mathrm{H}}}\right]^{+} \rightleftharpoons \\
\mathrm{H}-\stackrel{\mathrm{C}-\mathrm{O}-\mathrm{NO}_{2}+\mathrm{H}+:}{\rightleftharpoons}
\end{gathered}
$$

Obviously, the presence of water would enhance the reversal of the primary attack.

Dr. L. Bloch-Frankenthal's help in this work is gratefully acknowledged.

Scientific Department

Shalom IsRaklashVILI*

Israeli Ministry of Defence.

* Department of Organic Chemistry, The Hebrew University, Jerusalem.

${ }^{2}$ Berl, Andress, and Escales, Kunststoffe, 27, 23 (1937). Vandoni, Mem. Services chim. de L' Etat, 31,87 (1944).

${ }^{2}$ Hough, U.S.P. 751,706 .

${ }^{3}$ Fabel, Nitrocellulose, 13, 3, 27, 45 (1942).

- Caesar et al., J. Amer. Chem. Soc., 68, 372 (1946) ; ibid., 69, 617 (1947).

5 Farmer, J. Soc. Chem. Indust., 50, 75 T (1931).

- Bennett, Brand and Williams, J. Chem. Soc., 869, 875 (1946). Westheimer and Kharasch, J, Amer. Chem. Soc,, 68, 1871 (1946). heimer and Kharasch, Nat Amer.

${ }^{7}$ Nitrogen pentoxide in its free, undissolved state, is not nitronium nitrate, as can be concluded from the observation reported by nitrate, as can be concluded from
Hantzsch (Ber., 53, 941; 1925).

B (hedin, C.R. Acad. S $S^{\prime} i$., Paris, 201, 552 (1935).

- Chedin and Pradier, C.R. Acad. Sci., Paris, 203, 322 (1936).

\section{Dielectric Properties of Solid Hydrogen Bromide}

WE have recently extended the measurements of Smyth and Hitchcock ${ }^{1}$ on solid hydrogen bromide both in frequency and temperature-range, and our results given in terms of the real $\left(\varepsilon^{\prime}\right)$ and imaginery $\left(\varepsilon^{\prime \prime}\right)$ parts of the dielectric constant agree where the comparison is possible with those of the above authors.

The values of $\varepsilon^{\prime}$ and $\varepsilon^{\prime \prime}$ as a function of frequency, with the temperature as a parameter, are shown in the accompanying diagram, and we see that there is a variation of dielectric properties with frequency, for the frequency-range covered, only for temperatures below that of the lowest transition $\left(\sim-183^{\circ}\right.$ C.). The measurements were made at constant tem. perature and variable frequency, and for the series of measurements the temperature was not allowed to rise above $-184^{\circ} \mathrm{C}$, since the measured values are not exactly reproducible after passage through the transition. Moreover, the velues of $\varepsilon^{\prime}$ below $-184^{\circ} \mathrm{C}$. may vary by as much as 25 per cent according to the way of freezing the liquid hydrogen bromide in the dielectric cell. Consequently the 